\title{
Australian student visas: Assessing how the GTE requirement is assessed
}

\author{
NISHADEE PERERA
}

\section{Abstract}

Australia is a country that has long sought to be competitive in the international education sector, for the purposes of both revenue generation and contribution towards Australia's social fabric. However, it has also historically had ambivalent views concerning migration, since the days of the 'White Australia' policy. Given this socio-legal background, on 5 November 2011 the Genuine Temporary Entrant (GTE) requirement was introduced as part of Australia's Student Visa Program. It sought to maintain the integrity of Australia's international education sector, as well as enhance the sector's global competitiveness. However, industry experts have expressed concern over the requirement, suggesting that its application has been subjective and lacked transparency. This essay examines the GTE requirement through two cases submitted for review to the Migration Review Tribunal (MRT), to consider whether these concerns are evident at an appellate level. The essay will compare Australia's requirements with Canada's, taking into account broader policy objectives and the aforementioned goals. It will conclude that Australia's GTE test is subjective, evidenced by unclear and inconsistent decisions that lack transparency.

\section{Introduction: A background to the GTE requirement}

The Genuine Temporary Entrant (GTE) requirement was introduced on 5 November 2011, as part of a series of reforms pursuant to a strategic review commissioned by then Minister for Immigration Chris Bowen and then Minister for Education Chris Evans to enhance the competitiveness and maintain the integrity of the Australian Student Visa Program. ${ }^{1}$ The GTE requires the minister to be satisfied that the applicant genuinely intends to stay in Australia temporarily,

1 Michael Knight, 'Strategic Review of the Student Visa Program' (Report, Australian Government, 30 June 2011), v, x; Department of Immigration and Border Protection, Review of the effectiveness of the Genuine Temporary Entrant (GTE) requirement (2013) 4. 
having regard to the applicant's circumstances, immigration history and 'any other relevant matter'. ${ }^{2}$ These Schedule 2 requirements for the Student (Temporary) (Class TU) visas are given further guidance by Ministerial Direction No. 53 made under section 499 of the Migration Act 1958 (Cth). Though these directions do not force decision-makers to make a particular conclusion in individual cases, and decision-makers can take other factors into account, they are highly instructive and are meant to ensure consistent application of the regulation. ${ }^{3}$ Whilst the legislation maintains that a visa must be granted if an applicant satisfies the criteria, the subjectivity of the test and its consequent application has raised concerns for a number of education providers. ${ }^{4}$

Under the Howard Coalition Government, there was an apparent nexus between obtaining a student visa and gaining permanent residency in Australia. ${ }^{5}$ During this period, the international education sector became Australia's third largest source of export income by contributing $\$ 16.3$ billion to the Australian economy in 2010-2011 and generating over 100,000 jobs. ${ }^{6}$ However, such a nexus appears to have been cynically branded as the ability to 'buy' permanent residency in Australia 'for the cost of a two year VET level qualification'. ${ }^{7}$ As a result, the Knight review recommended that Australia ought to have 'more sensible criteria' to ensure that the sector's integrity is not being 'undermined by people seeking a migration outcome rather than an educational outcome'. ${ }^{8}$ Therefore, the goals of the GTE requirement appear to be one of maintaining integrity, in the context of a wider goal of global competitiveness.

However, education providers heavily question whether the GTE requirement is in fact 'sensible'. Following an internal review of the GTE requirement by the Department of Immigration and Border Protection (DIBP) in 2013, a series of international education providers such as the Independent Schools Council of Australia, English Australia, and the Australian Council for Private Education and Training submitted reports outlining their concerns. ${ }^{9}$ It ought to be noted,

2 Migration Regulations 1994 (Cth), sch 2, paras 570.223, 571.223, 572.223, 573.223, 574.223, 575.223, 576.222 .

3 See Howells v Minister for Immigration \& Multicultural \& Indigenous Affairs (2004) 139 FCR 580, 587-598; SAAC v Minister for Immigration \& Multicultural \& Indigenous Affairs (2004) 85 ALD 202, 220.

4 Migration Act 1958 (Cth), s 65.

5 Sudrishti Reich, 'Changes in the Student Visa Program - Expected and Other Consequences' (2012) 51 Immigration Review Bulletin 1, 5 .

6 Australian Bureau of Statistics, 'Australian Social Trends - International Students' (Catalogue no. 4102.0, December 2011) 1. www.ausstats.abs.gov.au/ausstats/subscriber.nsf/LookupAttach/4102.0Publication14.12.113/ \$File/41020_International_Dec2011.pdf.

7 Reich, above n $5,6$.

8 Knight, above n 1 , xi.

9 Independent Schools Council of Australia, Submission to Department of Immigration and Border Protection, Review of the Genuine Temporary Entrant (GTE) requirement, 28 March 2014; English Australia, Submission to Department of Immigration and Border Protection, Review of the Genuine Temporary Entrant requirement, 21 March 2014; Australian Council for Private Education and Training, Response to Department of Immigration and Border Protection, Review of GTE Criteria, March 2014. 
however, that those who made submissions are private education providers, suggesting that the GTE requirement primarily affects that particular portion of the international education sector.

Principally, the submissions pointed to the subjective nature of the test, which raised issues of whether the DIBP officer conducting the interview correctly understood the nature of the international education sector in order to apply the test. ${ }^{10}$ Furthermore, some reports indicate that the GTE requirement was one of many factors that contributed to a downturn of $\$ 2.5$ billion in revenue in the international education sector. ${ }^{11}$ While DIBP advised that a series of quality assurance measures had been implemented, the submissions of the education providers' concerns were made subsequent to DIBP's review. ${ }^{12}$ Ultimately, it is questionable whether the 'assurance measures' are sufficient. A fundamental aspect of maintaining the integrity of the sector, and Australia's international reputation more broadly, and thus competitiveness, is to have decision-making procedures that are transparent and accountable. ${ }^{13}$ It is unclear whether the GTE requirement in its current form strikes a balance between the flexibility such a subjective test provides, and the requisite transparency and accountability needed to maintain the integrity that was the goal of the reforms.

This essay will examine the GTE requirement by looking at two cases submitted for review to the Migration Review Tribunal (MRT), and evaluate whether concerns of subjectivity and transparency are legitimate. Considering the GTE requirement from the perspective of its aforementioned goals, and taking into account Australia's broader economic and foreign policy objectives, the article will then compare Australia's GTE requirement to that of Canada. Ultimately, it will argue that Australia's test is in fact subjective, and the reasoning for decisions can be unclear, appear inconsistent and lack transparency. Whilst it is within a sovereign state's power to decide whom to admit into their country, Australia must consider whether the current subjective and apparently inconsistent application of the GTE requirement aligns with Australia's broader economic interests and how this affects Australia's international reputation. ${ }^{14}$

10 Immigration National Office, 'PAM3: GenGuideG, Student visas - Visa application \& related procedures' (Procedure Advice Manual, 5 November 2011) 1; Independent Schools Council of Australia, above n 9, 2-3; English Australia, above n 9, 4-5.

11 Mark Glazbrook, GTE requirements hurting both international students and the economy (20 January 2014) Migration Solutions, www.migrationsolutions.com.au/news/gte-requirements-hurting-both-internationalstudents-and-the-economy/, citing a publication by Deloitte Access Economics.

12 Commonwealth Ombudsman and Overseas Student Ombudsman, Submission to Department of Immigration and Border Protection, Future for Streamlined Visa Processing Discussion Paper, 16 December 2014, 4. 13 Joo-Cheong Tham and Beth Gaze, 'Accountability and Transparency Under the Subclass 457 Visa Program: Is There a Cause for Concern?' (2014) 21 Australian Journal of Administrative Law 139, 140, 143.

14 Catherine Dauvergne, Humanitarianism, Identity, and Nation: Migration Laws of Australia and Canada (UBC Press, 2005) 52. 


\section{Case studies}

The following cases had contrasting outcomes. The facts are outlined separately with the reasoning later contrasted to highlight the apparent inconsistencies.

\section{Facts of decision A}

The applicant was a Macedonian national and applied for a Student (Temporary) (Class TU), subclass 572 visa, with his wife and children as secondary applicants. ${ }^{15}$ Entering Australia in 2010, he had completed a series of English courses, ${ }^{16}$ and certificates relating to engineering as he had an engineering qualification in Macedonia. ${ }^{17}$ The applicant also had his father, brother, family home and a jointbusiness with his brother in Macedonia. Hoping to take on a supervisory and management role in the business, he studied for a Diploma of Management. ${ }^{18}$ After falling ill in 2014, he decided that he would be unable to undertake the physical strain that his previous qualifications required. Thus he decided to embark on an IT qualification and he enrolled in an Advanced Diploma of Network Security. This diploma required the 572 visa under consideration. ${ }^{19}$ The Tribunal found that the applicant failed to satisfy the GTE requirement. ${ }^{20}$

\section{Facts of decision B}

The applicant was a Pakistani national, and had entered Australia in order to study IT. Changing his mind, he decided to study for a Diploma in Business. ${ }^{21}$ Deciding that he needed specific industry skills to engage in business, he decided to study an automotive specialist course. The institution where he had undertaken these courses closed down, and he decided to go back to studying business at a different institution. After enrolling in a Diploma of Management, he discovered a love of baking and pastry. Consequently, he enrolled in retail baking, and obtained employment in a cheesecake shop. Afterwards, he once again enrolled in a Diploma of Business, but discontinued these studies in order to pursue studies in advanced baking. Afterwards, he enrolled in a Diploma of Marketing, which required the 572 visa under consideration. ${ }^{22}$ Here, the Tribunal found that the applicant did satisfy the GTE requirement. ${ }^{23}$

151408418 [2014] MRTA 2824 (24 November 2014).

16 Ibid [18].

17 Ibid [19].

18 Ibid [22].

19 Ibid [17].

20 Ibid [55].

211410343 [2014] MRTA 2939 (5 December 2014).

221410343 [2014] MRTA 2939 (5 December 2014) [10].

23 Ibid [19]. 


\section{Comparing the reasoning in both decisions}

The reality of a subjective test is that different people may come to different conclusions. It is easy to inject doubt into the reasoning of the Tribunal members, however, as the subjective nature of the GTE requirement has been acknowledged; ${ }^{24}$ mere subjectivity does not appear to be an issue for legislators. Instead, it is more valuable to contrast the two decisions in order to highlight the inconsistencies in the application of the GTE requirement and factors provided in Ministerial Direction No. 53.

In decision $A$, the Tribunal member appears to have simply not believed the applicant's career path. She states that his decision to gain an IT qualification was a means of staying in Australia. ${ }^{25}$ However, in decision B, the Tribunal member states that studying IT is a 'classic case ${ }^{26}$ and did not question the applicant's true motives. Furthermore, the applicant in decision B appears to be far more indecisive in his career path. It appears that the Tribunal member was heavily swayed by a romantic and idealistic story of discovering a passion. Whilst this applicant did explain his goals with a business plan, so did the applicant in decision A. In fact, the applicant in decision $A$ already had a business to go back to. If anything, applicant A's career path is arguably more persuasive in arguing that he will return to Macedonia.

In decision $\mathrm{A}$, the Tribunal member stated that a business, home, brother and father do not provide a sufficient incentive to return to Macedonia, ${ }^{27}$ whereas in decision B, the family and business in Pakistan appear to be sufficient. Further, in decision $\mathrm{B}$, the applicant appears to intend to set up a new business, suggesting the family business is even less of an incentive to return than in decision $\mathrm{A}$. In coming to this conclusion, the Tribunal member in decision A states that the applicant had been able to manage the business over Skype for four years, and therefore has no reason to return, ${ }^{28}$ notwithstanding the applicant explaining that he needed to be there to structurally expand the business and purchase new equipment. ${ }^{29}$ It is unclear why the applicant's reasons are unpersuasive, as the Tribunal does accept that 'IT knowledge may be useful in the fabrication trade and the running of a business' ${ }^{30}$

24 Immigration National Office, above n 10, 1.

251408418 [2014] MRTA 2824 (24 November 2014) [50]

261410343 [2014] MRTA 2939 (5 December 2014) [12].

271408418 [2014] MRTA 2824 (24 November 2014) [47].

28 Ibid.

29 Ibid [36].

30 Ibid [37]. 
Using country information on Macedonia, the Tribunal member in decision A cites Australia's education system as an incentive to stay ${ }^{31}$ However, in decision B the Tribunal member does not question Pakistan's education system, even though he clearly puts his mind to the issue. ${ }^{32}$ World Bank data suggests that Macedonian education is in fact better than Pakistan with respect to primary, secondary and tertiary enrolment, as well as youth literacy. ${ }^{33}$ While Tribunal members may not be compelled to enquire to this level of depth, available country information demonstrates the inconsistencies in decision-makers' reasoning.

Ultimately, there are inconsistencies in the application of determinative factors, made evident when comparing the reasoning of these two decisions. This analysis does not suggest that the final outcomes were incorrect; rather, the inconsistency as the result of a subjective test affirms the concerns of many international education providers. In order to consider whether there is a more appropriate test, it is helpful to consider the approach of one of Australia's global competitors: Canada.

\section{The Canadian system}

Much like Australia, Canada is a country of immigrants which seeks to enhance and grow its labour force using immigration. ${ }^{34}$ The international education sector is part of this broader immigration policy, while it is also an export. ${ }^{35}$ Similar to Australia, Canada has a temporary entrant requirement, which requires a visa officer to be satisfied that a foreign national will leave Canada by the end of their authorised period of stay. ${ }^{36}$ The visa officer is to consider numerous factors, including financial and personal ties to the applicant's country of origin, past immigration attempts, whether the applicant has overstayed their visa in other countries and whether they have a criminal past. On its face, the Canadian test and the GTE requirement appear similar. However, the Canadian context seems to provide greater likelihood of consistent application. In particular, there is provision for dual intent. Further, it is common for temporary resident visa cases to go to judicial review on the grounds of unreasonableness, which helps create precedent for consistent application of the provision.

31 Ibid [43].

321410343 [2014] MRTA 2939 (5 December 2014) [15].

33 World Development Indicators, Literacy rate, youth total (\% of people ages 15-24) (2014) The World Bank, data.worldbank.org/indicator/SE.ADT.1524.LT.ZS/countries; World Development Indicators, School enrollment, primary (\% net) (2014) The World Bank, data.worldbank.org/indicator/SE.PRM.NENR/countries; World Development Indicators, School enrollment, secondary (\% net) (2014) The World Bank, data.worldbank.org/ indicator/SE.SEC.NENR/countries; World Development Indicators, School enrolment, tertiary (\% gross) (2014) The World Bank, data.worldbank.org/indicator/SE.TER.ENRR/countries.

34 Catherine Dauvergne, above n 14, ch 3.

35 Mary Crock and Kerry Lyon (eds), 'National Skilling - Migration, Labour and the Law' (Working Paper No. 11, Asia Pacific Migration Research Network, 2002) 26-45.

36 Immigration and Refugee Protection Regulations, SOR/2002-227, s 179(b). 
Firstly, the dual intent provision is stipulated in section 22(b) of the Immigration and Refugee Protection Regulations, and states that a foreign national's 'intention to become a permanent resident does not preclude them from becoming a temporary resident'. ${ }^{37}$ Decision-makers are given further guidance through Operation Bulletins, which provides that there may be instances where an applicant might have a longer-term plan in mind, but 'the onus is on the applicant to establish that they are a bona fide temporary resident that will leave Canada by the end of the period authorised for their stay ${ }^{38}$ While this provision has also attracted criticism in Canada due to misapplication, ${ }^{39}$ section 22(b) makes clear to decision-makers that a long-term, potential plan of permanent residency does not bar a prospective international student from applying for a visa. ${ }^{40}$

Essentially, Canada's main concern appears to be temporary entrants overstaying their visa, as opposed to the Australian concern of 'buying permanent residency'. ${ }^{41}$ However, like Canada, Australia does provide for talented, trained individuals to stay in Australia and enter the labour force through Australia's Skilled Migration Program. Therefore, the economic goals of the Student Visa Program can be twofold: increasing revenue by using education as an export, and increasing Australia's output by increasing, in certain sectors, the supply of a potential labour force. Therefore, to bar an applicant due to a potential longer-term plan appears inconsistent with Australia's wider economic goals. Moreover, Canada seems to maintain the integrity of their system by requiring the applicant to be enrolled in a 'designated learning institution'. ${ }^{22}$ This appears to be similar to Australian requirements such as enrolment in an institution listed on the Commonwealth Register of Institutions and Courses for Overseas Students (CRICOS). It is unclear why Australia needs the GTE requirement to maintain the integrity of the international education sector if student visas can be controlled through other mechanisms.

Secondly, in Canada, there appear to be more cases in which the temporary resident requirement goes to judicial review on the grounds of unreasonableness. ${ }^{43}$ While this does signify an expansion of judicial review on unreasonableness grounds, which is arguably undesired in Australia's administrative law context, ${ }^{44}$ decisions

37 Immigration and Refugee Protection Regulations, SOR/2002-227, s 22(b).

38 Citizenship and Immigration Canada, 'Operational Bulletins 131 - Application of Dual Intent' (Operational Manual, July 6 2009) www.cic.gc.ca/english/resources/manuals/bulletins/2009/ob131.asp.

39 Standing Committee on Citizenship and Migration, House of Commons, Protecting Canada and Canadians, Welcoming the World: A Modern Visa System to Help Canada Seize the Moment (2014) 18.

40 Citizenship and Immigration Canada, above n 38.

41 Reich, above n 5, 6.

42 Immigration and Refugee Protection Regulations, SOR/2002-227, s 219.

43 See for example: Japal Singh Dhanoa v The Minister of Citizenship and Immigration [2009] FC 729; Tharsini Thiruguanasambandamurthy $v$ The Minister of Citizenship and Immigration [2012] FC 1518; Jaspreet Singh Momiv The Minister of Citizenship and Immigration [2013] FC 162.

44 Robyn Bicket, 'Controlling Immigration Litigation: The Commonwealth Perspective' (2010) 63 Australian Institute of Administrative Law 40, 41-42. 
from the courts have provided clearer guidance for the application of the test. It must be noted that reasonableness is itself an imperfect test. ${ }^{45}$ However, for many applicants, a judge's decision would allow for more consistent application due to the precedential weight a judgment carries. Coupled with the dual intent provision in section 22(b), judicial review in Canada has explicitly created precedent as to the purposes of dual intent and the temporary entrant requirement; namely to avoid over-generalisation of applicants' motives, ${ }^{46}$ and to limit, as Harrington J stated, 'sanctimonious' reasoning, such as Canada 'is more of a draw ${ }^{37}$ than the applicant's home country. Overall, the increased judicial review of Canada's system may not necessarily be desired in Australia; however, this context is important in analysing the consistent application of a highly discretionary and subjective test such as the temporary entrant requirement.

\section{Conclusion}

The GTE requirement was introduced to enhance the integrity of Australia's international education system, while maintaining its global competitiveness. With these goals in mind, from an economic and foreign policy perspective, the inconsistencies of the test are problematic. Due to the highly subjective nature of the test, the inconsistencies in application are evident when comparing decisions with similar circumstances, but opposite results. From this perspective, the concerns of international education providers appear valid. An inconsistent, highly subjective test that consequently lacks transparency damages the sector. The test appears to be at odds with Australia's economic goals of increasing revenue from the sector and such a test can damage the reputation of Australia's international education sector, which can have further ramifications in Australia's foreign affairs. Moreover, the integrity of the system can be maintained using other means, such as restricting registered courses. While global competitors such as Canada may have a similar requirement, the context of the test is different. The Canadians make provision for dual intent in order to bring clarity to the application of the test and the nature of judicial review in Canada more readily provides oversight and guidance, which ensures consistent and sound reasoning. If Australia truly desires to ensure the integrity of the international education sector, while maintaining its competitiveness and value as an export, Australia needs to reconsider the application of the GTE requirement, and decide whether it actually aligns with Australia's broader economic and foreign policy goals.

45 Chris Wheeler, "What is "fair" and "reasonable" depends a lot on your perspective' (2014) 22 Australian Journal of Administrative Law 63, 68-69.

46 Tharsini Thiruguanasambandamurthy $v$ The Minister of Citizenship and Immigration [2012] FC 1518, [16], [20], [32].

47 Japal Singh Dhanoa v The Minister of Citizenship and Immigration [2009] FC 729, [16]. 


\section{Bibliography}

\section{Journal articles/books/working papers}

Bicket, Robyn, 'Controlling Immigration Litigation: The Commonwealth Perspective' (2010) 63 Australian Institute of Administrative Law 40.

Crock, Mary and Kerry Lyon (eds), 'National Skilling - Migration, Labour and the Law' (Working Paper No. 11, Asia Pacific Migration Research Network, 2002).

Dauvergne, Catherine, Humanitarianism, Identity, and Nation: Migration Laws of Australia and Canada (UBC Press, 2005).

Reich, Sudrishti, 'Changes in the Student Visa Program - Expected and Other Consequences' (2012) 51 Immigration Review Bulletin 1, 5.

Tham, Joo-Cheong and Gaze, Beth, 'Accountability and Transparency Under the Subclass 457 Visa Program: Is There a Cause for Concern?'(2014) 21 Australian Journal of Administrative Law 139.

Wheeler, Chris, 'What is "fair" and "reasonable" depends a lot on your perspective' (2014) 22 Australian Journal of Administrative Law 63.

\section{Reports/submissions/other studies}

Australian Bureau of Statistics, 'Australian Social Trends - International Students' (Catalogue no. 4102.0, December 2011) 1. www.ausstats.abs.gov.au/ausstats/ subscriber.nsf/LookupAttach/4102.0Publication14.12.113/\$File/41020_ International_Dec2011.pdf.

Australian Council for Private Education and Training, Response to Department of Immigration and Border Protection, Review of GTE Criteria, March 2014.

Commonwealth Ombudsman and Overseas Student Ombudsman, Submission to Department of Immigration and Border Protection, Future for Streamlined Visa Processing Discussion Paper, 16 December 2014.

Department of Immigration and Border Protection, Review of the effectiveness of the Genuine Temporary Entrant (GTE) requirement (2013).

English Australia, Submission to Department of Immigration and Border Protection, Review of the Genuine Temporary Entrant requirement, 21 March 2014. 
Independent Schools Council of Australia, Submission to Department of Immigration and Border Protection, Review of the Genuine Temporary Entrant (GTE) requirement, 28 March 2014.

Knight, Michael, 'Strategic Review of the Student Visa Program' (Report, Australian Government, 30 June 2011).

Mark Glazbrook, GTE requirements hurting both international students and the economy (20 January 2014) Migration Solutions, www.migrationsolutions.com. $\mathrm{au} /$ news/gte-requirements-hurting-both-international-students-and-theeconomy/.

Standing Committee on Citizenship and Migration, House of Commons, Protecting Canada and Canadians, Welcoming the World: A Modern Visa System to Help Canada Seize the Moment (2014).

World Development Indicators, Literacy rate, youth total (\% of people ages 15-24) (2014) The World Bank, data.worldbank.org/indicator/SE.ADT.1524.LT.ZS/ countries.

World Development Indicators, School enrollment, primary (\% net) (2014) The World Bank, data.worldbank.org/indicator/SE.PRM.NENR/countries.

World Development Indicators, School enrollment, secondary (\% net) (2014) The World Bank, data.worldbank.org/indicator/SE.SEC.NENR/countries.

World Development Indicators, School enrolment, tertiary (\% gross) (2014) The World Bank, data.worldbank.org/indicator/SE.TER.ENRR/countries.

\section{Cases}

1408418 [2014] MRTA 2824 (24 November 2014).

1410343 [2014] MRTA 2939 (5 December 2014).

Howells v Minister for Immigration $\&$ Multicultural $\&$ Indigenous Affairs (2004) 139 FCR 580.

Japal Singh Dhanoa v The Minister of Citizenship and Immigration [2009] FC 729.

Jaspreet Singh Momi v The Minister of Citizenship and Immigration [2013] FC 162.

SAAC v Minister for Immigration $\&$ Multicultural \& Indigenous Affairs (2004) 85 ALD 202.

Tharsini Thiruguanasambandamurthy $v$ The Minister of Citizenship and Immigration [2012] FC 1518. 


\section{Legislation/delegated legislation}

Immigration and Refugee Protection Regulations SOR/2002-227.

Migration Act 1958 (Cth).

Migration Regulations 1994 (Cth).

\section{Manuals}

Citizenship and Immigration Canada, 'Operational Bulletins 131 - Application of Dual Intent' (Operational Manual, July 6 2009) www.cic.gc.ca/english/ resources/manuals/bulletins/2009/ob131.asp.

Immigration National Office, 'PAM3: GenGuideG, Student visas - Visa applicated \& related procedures' (Procedure Advice Manual, 5 November 2011) 1, www.immi.gov.au/gateways/agents/pdf/genguideg-visa-applicationrelated-procedures.pdf. 
This text is taken from The ANU Undergraduate Research Journal, Volume Seven, 2015, edited by Daniel McKay, published 2016 by ANU eView, The Australian National University, Canberra, Australia. 